\title{
Indonesian Teachers' Implementation of New Curriculum Initiatives in Relation to Teaching Writing in Lower Primary School
}

\author{
Sulfasyah $^{1, *}$, Yvonne Haig ${ }^{1} \&$ Caroline Barratt-Pugh ${ }^{1}$ \\ ${ }^{1}$ School of Education, Edith Cowan University, Mount Lawley 6050, Western Australia \\ *Correspondence: Faculty of Education, University of Muhammadiyah Makassar, 259 Sultan \\ Alauddin Street, Makassar 90222, Indonesia. Tel: 62-411-866-972 E-mail: \\ sulfasyah@yahoo.com
}

Received: September 18, 2015 Accepted: September 29, 2015 Published: December 18, 2015 doi:10.5296/ije.v7i4.8265 URL: http://dx.doi.org/10.5296/ije.v7i4.8265

\begin{abstract}
This paper reports an investigation of teachers' implementation of a new Indonesian curriculum, the Kurikulum Tingkat Satuan Pendidikan (KTSP), meaning school-based curriculum. The specific context chosen was the teaching of writing in Year 2 in the primary schools of Makassar City, Indonesia. The teachers' implementation was examined through the lens of the KTSP's key constructivist-based concepts. Using qualitative methods, the study found that the teachers' implementation of the new writing curriculum reflected a traditional view of teaching, despite the intent of the KTSP to move away from this approach to one that better reflected a constructivist approach. The study also revealed that the inconsistencies between the intentions of the KTSP and the basic competencies it mandated discouraged the teachers from changing their teaching and assessment practices. These findings have important implications for the development of policy and practice regarding the implementation of existing and future curricula in Indonesia and elsewhere.
\end{abstract}

Keywords: curriculum implementation, early writing, primary school 


\section{Introduction}

Teachers are considered to be one of the key factors in effective implementation of curriculum change (Fullan, 2007). While other parties reform the curriculum, it is the teacher who implements the changes to bring about reform (Stronge, 2010). In fact, teachers have been acknowledged in policy as key agents of change (Priestley, 2011). A number of studies from various contexts have explored in general how teachers implemented new curricula (Blignaut, 2008; Curtner-Smith, 1999; DeSegovia \& Hardison, 2009; Obara \& Sloan, 2009). However, little research has been conducted to examine in-depth how teachers implement a new curriculum, particularly in relation to the literacy curriculum at the lower level of primary school, in the Indonesian context.

The present paper addresses this dearth by focusing on primary teachers' implementation of a new Indonesian curriculum, the Kurikulum Tingkat Satuan Pendidikan (KTSP), which translated means school-based curriculum. Although the Indonesian government, through the Ministry of National Education (MONE), Republic of Indonesia, has developed a subsequent curriculum, partially implemented in July 2013, the KTSP is referred to as the 'new curriculum' in this paper because it was being implemented at the time of this study. The research reported here was concerned with the implementation of the KTSP in relation to Writing in Year 2 (Y2) in the primary schools of Makassar City, Indonesia.

Prior to the introduction of the KTSP, the teaching of early writing was generally delivered through a traditional teaching approach characterized by teacher-directed input and limited student participation, with an emphasis on skill-based learning. Sari (2012) identified this as the dominant mode of teaching in Indonesia for many years. It follows, then, that the student-centered approach to the teaching of writing required by the KTSP would demand a considerable change in practice, making it a compelling context within which to examine the implementation of the KTSP. This study emerged from an interest in understanding the processes and outcomes of curriculum reform in order that this knowledge might inform effective implementation of existing and future curricula in Indonesia and other similar contexts.

\section{Contextual Background}

\subsection{Policy Background}

MONE, Republic of Indonesia, launched a new curriculum - the KTSP - in 2006 to improve the previous Competency-Based Curriculum known as the KBK. Gradually introduced in primary schools across Indonesia from 2006, the KTSP became mandatory for each level of primary, junior and senior high school in the country beginning in the academic year of 20092010 (Peraturan Menteri Pendidikan Nasional No. 24, 2006).

As with the KBK, the KTSP was competency based (Muslich, 2007). It was designed to allow individual schools to develop their school-based curriculum with reference to the competencies and content standards outlined in the Curriculum Policies and Curriculum Guidelines 
established by the government (Peraturan Menteri Pendidikan Nasional No 24, 2006). The central role played by the competencies and content standards ensured that students across Indonesia met common minimum standards, while allowing schools to set higher standards appropriate to their local context.

While the KTSP aimed to increase school autonomy through a competency-based approach, it brought with it the demand for significant changes in the roles and practices of Indonesian teachers. In an attempt to move away from a more traditional method of teaching, the Curriculum Policies and Curriculum Guidelines, through the description of several key teaching and learning concepts, either explicitly or implicitly delineated the pedagogy and overall approaches to teaching that should be employed to achieve the minimum competencies and content standards. As stated previously, student-centered learning formed the basis of the KTSP and teachers were encouraged to use a range of related learning processes. These included active learning in which the teacher acted as facilitator; and interaction among the students, between the students and the teachers, between students and the environment, and between students and other learning resources to achieve the basic competencies. Finally, various types of assessment were recommended to ascertain the students' learning processes and educational outcomes in relation to the intended competencies (BSNP, 2006). These changes appeared to be informed by constructivist theory (Pusat Kurikulum, 2010; Sanjaya, 2008).

Constructivism is a theory of learning that focuses on the nature of knowledge and how learners construct knowledge meaningfully (Cox, 2005; Tompkins, 2008). Constructivist learning represents a paradigm shift from behaviorist approaches to education to those based on cognitive and social theories of learning (Kaufman, 2004; Tompkins, 2008). Within this view, however, there are different perspectives on how learners construct new knowledge. The perspective that appears to inform the KTSP (BSNP, 2006) is social constructivism; a view strongly associated with the work of Vygotsky (1978). This perspective stresses that children learn new knowledge by being active participants in meaningful social interaction with other people (Fosnot, 2005; Kaufman, 2004).

The discussion above reveals the complexity of the new curriculum implementation in Indonesia where the competencies were standardized in a government framework. According to this framework, schools were required to integrate these standardized competencies into school-developed curricula and teachers were expected to ensure the competencies' achievement by using student-centered and active learning methods. Research suggests that the success of attempts to meet competencies using various active learning methods depends on the nature of those expected competencies. On the one hand, competencies that are broad and complex promote higher-order thinking; on the other hand, competencies that are narrow and very skill-based tend to lead to a learning process that is behaviorist (Bowden, 1997). Thus, it may be highly challenging for teachers to incorporate active learning methods into their teaching if the expected competencies are very narrow and skill-based.

The KTSP curriculum guidelines provided steps for teachers to prepare their syllabus by identifying competencies and then selecting the content, method of instruction and assessment 
to support student attainment of those competencies (BSNP, 2006). Wiggins and McTighe (2005) termed this approach 'backward design'. Although few empirical studies have been conducted to investigate the effectiveness of backward design, many teachers have used this design and perceived it as an effective approach (Fox \& Doherty, 2011; Graff, 2011). Wiggins and McTighe (2015) identified three ways that teachers could approach this process, depending on the skills and knowledge to be achieved through the learning activities. The different approaches they identified were direct or didactic instruction, coaching, and constructivist methods of facilitating learning. They stated that direct instruction and focused coaching are suitable to teach knowledge and skills that are isolated, simple and enabling, while constructivist facilitation is appropriate for teaching those ideas that are subtle, prone to misunderstanding, and in need of personal inquiry, testing and verification. This implies that the instructional methods used in backward design depend to some extent on the nature of the expected learning outcomes.

The teaching of writing in Indonesian primary school forms part of the general Indonesian language classes - Bahasa Indonesia being one of the core subjects at all levels of schooling. The teaching of Bahasa Indonesia includes four language skills: listening, speaking, reading and writing. Under the KTSP, each of these skills has a number of competency standards and basic competencies that students must demonstrate at the end of each semester, the end of a grade and on leaving school.

A traditional approach was taken to the teaching of early writing in Indonesia before the implementation of the KTSP. This approach depends on teacher-directed activities that focus more on the product than the process (Browne, 1993). For instance, under a traditional approach, teachers direct students to practice written language as an isolated skill without reference to a meaningful context, so that the focus is on the rules of grammar, spelling, capitalization, punctuation, letter formation, neatness, presentation and exercises intended to improve sentence-level development (Browne, 2009). Writing activities include having children copy words from the black/white board, trace over the teacher's writing, or copy models of writing - all with a particular focus on neat writing and correct spelling. There may be opportunities to compose stories, but even this task is designed to provide practice in specific skills, and feedback from the teacher is primarily concerned with neatness of the writing rather than content (Browne, 1993; Cox, 2005). Further, in a traditional approach, classroom interaction takes the form of teachers initiating talk or activities, students responding and teachers evaluating that response. This type of classroom discourse is common in didactic approaches and is known as IRE, which stands for Initiation, Response and Evaluation (Perrott, 1988).

Such practices are common in the classrooms across Indonesia (MBE-USAID, 2003; Sari, 2012). Results of classroom observations in primary schools conducted by a foreign organization in Indonesia (MBE USAID, 2003) showed that the teachers' role was dominant in the classroom and the interaction was predominantly one way; that is, from the teacher to the student. Furthermore, teachers initiated about $95 \%$ of the questions and the form of questions belonged to lower-order thinking. To assess the students' achievements, the teachers only administered formal tests, given daily or at the end of the term. Thus, the recent 
incorporation of key concepts influenced by a constructivist approach to the teaching of writing promoted by the KTSP would require a significant change in practice. The following section highlights the key aspects of implementation of curriculum change relevant to this study.

\subsection{An Overview of Curriculum Change}

As noted by Marsh (2004), a curriculum begins as a written plan or product and is only realized once teachers implement it with students. The implementation phase involves the actual use of a curriculum (Fullan \& Pomfret, 1997) and it "consists of the process of putting into practice an idea, program or set of activities and structures new to the people attempting or expected to change" (Fullan \& Stiegelbauer, 1991, p.65).

A number of recent studies of curriculum implementation in developing countries reveal that new curricula have not been put into practice as intended by the curriculum developer (Blignaut, 2008; Curtner-Smith, 1999; DeSegovia \& Hardison, 2009; Obara \& Sloan, 2009; Pusat Kurikulum, 2007). For example, DeSegovia and Hardison in their study concerned with the implementation of a new English curriculum in Thailand reported that the teachers involved struggled with the introduction of new pedagogical concepts promoted in the new curriculum. In the Thai case, the reform mandated a shift from a teacher-centered to a learner-centered approach involving all subjects including English. However, DeSegovia and Hardison's study found no evidence of the teachers implementing the new approach as suggested but, rather, they delivered subjects using their old practices. Similarly, Blignaut (2008) found that learner-centered practices promoted in a new curriculum in South Africa appeared to be non-existent in teachers' classrooms. In addition to this, it was found that assessment practices did not reflect the intent of curriculum policy.

A previous Indonesian research study on curriculum implementation at the national level was conducted by the Indonesian Curriculum Research Centre, which is a government agency operating under the Department of National Education (Pusat Kurikulum, 2007). The purpose of the study was to monitor the implementation of the KTSP in primary, junior high and senior high schools at the national level. The study was conducted in the capital cities of 33 provinces across Indonesia and it revealed that most of the schools involved had not implemented the KTSP effectively. Several factors influencing this lack of success were identified. These included but were not limited to the following two key issues: information about the KTSP was not delivered efficiently and equally across the country; and most schools and teachers in the study stated that they received inconsistent information about the KTSP from one professional development (PD) course to another. As a result, teachers found it confusing to implement the curriculum at the school and classroom level. For example, most of the participants in the study appeared to understand the Curriculum Policies at the surface level but did not understand the substance of the KTSP, nor did they know how to implement it in ways consistent with its core concepts. Moreover, the training given was not consistent with the teachers' expectations that the training would focus on the teaching and learning strategies to implement the KTSP. 
The studies discussed above illustrate that effective change will only occur if teachers, as key curriculum implementers, have a clear understanding of the need for change and of the change itself and have the opportunity to develop critical new knowledge, skills and attitudes (Fullan, 2007). These studies also suggest that teachers require appropriate and effective training if they are to attend to changes (Broadhead, 2001; Fullan, 2007; Guskey, 2000).

The need for effective training is particularly important with the implementation of a constructivist approach to learning as it is complex and demands much from the learner and teacher (Alesandrini \& Larson, 2002; Windschitl, 2002). The change of role from knowledge transmitter to learning facilitator encouraged in the constructivist approach suggests that a totally different set of pedagogical skills is required (Weimer, 2002). Unless teachers are well trained and supported, they will easily return to familiar practices (Broadhead, 2001). Therefore, teachers should be encouraged to understand change at a deeper level and implement it gradually with appropriate support and assistance (Fullan, 2007; Little, 2001).

The most commonly discussed form of support for teachers' implementation is professional development (Putman, Smith, \& Cassady, 2009). A number of studies have shown the positive impact of PD on teachers' knowledge and capacity for change (Garet, Porter, Desimone, Birman, \& Yoon, 2001; Peneul, Fishman, Yamaguchi, \& Gallagher, 2007). However, in order to be effective, PD should be constant, rather than a once-off program with little follow-up (Fullan, 2007; Guskey, 2000). Garet et al. (2001) in their study about effective PD for teachers found that it was likely to have a more effective impact when its delivery was sustained and intensive. Garet and colleagues also found that teachers' knowledge and skills improve when PD focuses on content that encourages active learning and is integrated into the daily life of the school.

\section{Methodology}

This study was designed to investigate how teachers implemented the writing component of the KTSP in Y2. The teachers' implementation was investigated through the lens of five key concepts taken from the KTSP. These were student-centered learning, active learning, the role of the teacher as a facilitator, students' interaction as a means of promoting learning, and assessment for learning. The researcher chose these key concepts as a framework to investigate the teachers' implementation because they encompass its underlying philosophical framework and are central to classroom practices recommended by the Curriculum Policies.

The component of the study reported in this paper addressed the question: How do teachers implement the KTSP in teaching writing to Y2 students? Data were collected using qualitative methods of investigation (Creswell, 2012), comprising classroom observation followed by informal discussion, interviews and document analysis. Such data-collecting approaches acknowledge the role of context in phenomena, provide flexibility and give the participants a voice (Robson, 2011). Further, the use of a range of methods allows for richer data and triangulation of findings (Creswell, 2012). The ten teachers who participated were drawn from the 61 Y2 teachers, across 29 schools, who responded to a survey informing the larger 
research project of which this study was part. These teachers, all of whom were female and between 28 and 55 years old, were conveniently selected on the basis of the location of their school's sub-district, thus ensuring the sample was representative of a range of contexts and socio-economic conditions.

At the time of the study, all 10 participating teachers had taught Y2 for at least three years. Three teachers commenced implementation of the curriculum in 2007, five in 2008 and two in 2009. Further, data from the survey indicated that all 10 teachers had attended PD related to the KTSP. However, most of this PD presented information about general aspects of the KTSP and focused on the following three areas: information about the background of the KTSP, which covered all the regulations related to this curriculum; matters to consider when developing the KTSP; and the development of the syllabus and lesson plans. Two teachers had received training on the teaching and learning of literacy subjects within the KTSP, and these focused on the teaching of handwriting. A further two had attended PD related to the models of teaching suggested by the KTSP. In addition, four of the teachers reported having attended PD delivered by the Department of Education at the provincial level. The teachers who had not attended in-service training about the KTSP delivered by the Department of Education claimed to have learned about it from a seminar, which was organized by local universities, from their Y2 colleagues, who had attended PD delivered by the Department of Education or from a Teacher Working Group.

The procedures used to collect the qualitative data included 40 classroom observations in which the researcher acted as a non-participant observer. These observations were conducted over approximately three months in the classrooms of the 10 teachers while they taught writing lessons. The lessons were nominated by the teachers on the basis that they demonstrated how the teachers typically taught writing under the KTSP. Each observation was approximately 70 minutes in duration. These classroom observations were recorded through field notes guided by general categories determined by the research question. The categories included the role of the teachers and the students, the nature of the classroom interaction, the content of the lesson, the writing activities that formed part of the lesson, and the assessment practices. These categories represent the key concepts underpinning the KTSP.

Each teacher was observed teaching four separate writing lessons. The first observation took a general focus so the researcher could become familiar with the classroom setting and research procedures; thus, the data collected in this observation were not used in the analysis. The data from the remaining three observations included the field notes related to the pre-determined categories as well as unique and unanticipated phenomena that emerged during the lessons. Informal discussions followed each of these observations to allow for clarification of any issues or questions that arose and to give the teachers the opportunity to comment on any aspect of their lessons. At the completion of all the observations, semi-structured interviews, which were audio recorded, were conducted with each of the 10 teachers to explore in more depth key aspects of their implementation of the KTSP writing lessons. The content of the questions included but was not limited to the descriptions and explanations of practices observed in the lessons and assessment of the students' writing produced in their Y2 writing lessons. The audio recordings of these interviews were 
transcribed and analyzed to document emergent themes and categories, which were subsequently related to the findings from the observations.

Document analysis of the lesson plans for each observed lesson further enhanced exploration of teacher practices. These plans provided written evidence of the teaching intentions, instructional methods to be used and outcomes anticipated in each of the 40 lessons. Document analysis of 90 samples of students' writing completed in the observed lessons strengthened this evidence. The teachers nominated these samples as examples of the types of writing produced in their writing lessons, the level of competence usually demonstrated and of the assessment criteria they used to evaluate their students' learning. Further, the samples assessed provided evidence of the outcomes of the teachers' pedagogical practices, deepening the evidence concerning the teachers' implementation of the KTSP in writing.

The data from the observations, informal discussions, lesson plans and writing sample analysis were coded separately to identify emergent themes and then these were clustered into categories. These four data sets were then collated to identify common themes and categories, thereby enriching and triangulating the findings.

Before the study was conducted, the semi-structured interview and classroom observation protocols were trialed with two teachers who had responded to the survey in Phase 1 of the study, but who were not be involved in the second phase. The trials ensured that the interview protocol contained pertinent, suitably structured questions, ascertained the length of time to be taken by each interview and ensured that the observation protocol enabled the researcher to document in detail key elements of the writing lesson.

To ensure that the findings and interpretation in this study were valid and accurate, this study used two strategies: triangulation and member checking (Cresswell, 2012). The triangulation process was conducted by corroborating evidence from different methods of data collection, such as the questionnaire, observations, interviews and document analysis. This process ensures the accuracy of the findings as the information is drawn from multiple sources (Cresswell, 2012). The second strategy, member checking, refers to a process in which one or more participants in the study check the accuracy of the findings or interpretation of them (Cresswell, 2012). In this study, seven participants were available for member checking and were given a summary of the findings. They were asked whether the findings reflected their opinions and whether the interpretation was fair and representative. All reported that both the findings and interpretation matched their situation. In addition to these strategies, the researcher's considerable experience as a teacher educator and assessor in a teacher certification program in Indonesia, and as a holder of a Masters degree in language arts in primary education strengthened the credibility of the interpretations made in this study.

\section{Findings}

This study identified two main findings regarding the teachers' implementation of the KTSP in relation to teaching writing. First, the teachers demonstrated a traditional teaching approach in their writing lessons. Second, the teachers appeared to restrict their teaching of 
writing to those aspects that assisted their students to achieve the Basic Competencies for Y2, as mandated in the KTSP.

Finding 1: Teachers 'practices reflected a traditional view of learning when implementing the writing component of the KTSP

While the KTSP, through the curriculum policies and guidelines, promoted learning experiences based on social constructivist perspectives, the evidence from this study suggests that the teachers' implementation was consistent with a traditional approach in which learning was teacher-directed. The teachers' traditional approach was observable in many aspects of their practice when conducting writing lessons and evidenced in their informal discussions, semi-structured interviews, lesson plans and students' writing samples. Firstly, it was reflected in the teachers' role in the classroom, which could be characterized as predominantly teacher-centered. It was evident that the teachers were dominant in orchestrating activities in the classroom. For example, all 10 teachers reported that they determined all the topics to be addressed by writing and all the activities or assignments to be completed. Moreover, in all observed lessons, the teachers were seen to focus on the transmission of knowledge rather than facilitating students to construct their own knowledge, and all the students in each class were observed undertaking similar teacher-directed writing tasks.

Teacher-centeredness was particularly evident in the way all 10 teachers presented their lessons, which, regardless of the different backgrounds of the students and the varying contexts of the schools, were observed to follow a similar procedure. For example, in all the observed classes, the teachers began each writing lesson by either stating or explaining the learning objectives or goal. This was followed by a short review of the previous lesson characterized by the teacher describing what had been done and asking the students literal questions about the content. Next, the teachers presented the new learning topic followed by step-by-step guided practice in which the students worked individually under teacher direction. During guided practice, the teachers gave feedback by correcting students' work orally. Lastly, the students undertook independent practice by undertaking the same set tasks which, when completed, were collected for marking. In each observation it appeared that the students were passive recipients of teacher instruction, with no evidence of facilitation of learning in ways consistent with constructivist perspectives.

Secondly, the teachers' traditional approach to teaching writing was evident in the nature of the classroom interaction, which followed the pattern typical of 'initiation, response and evaluation' (IRE) (Perrott, 1988). For example, in each of the 30 analyzed writing lessons, the teacher always led the talk and the interaction followed a common procedure whereby the teachers would initiate a question, call on a student, who responded, and then evaluate the answer as either correct or incorrect. This type of interaction was particularly evident after the students had read the same short text from their textbooks and was followed by the teachers assigning writing activities, such as copying or dictation. This was exemplified in the following dialogue from one observed class between a teacher and her students about a short story. 
Teacher: What happened with Rika yesterday?

Students: She was ill.

Teacher: Good. Did she go to school?

Students: No, she did not.

Teacher: Good. Who took her to the hospital?

Students: Her mother.

This typical interactive sequence suggests that the students had little opportunity to develop or comment on ideas in the text when the only thing required was 'correct' answers to the teachers' literal questions about its content.

Only three observed lessons from two classrooms involved interaction between students when they worked in pairs or small groups. In these contexts, the teachers initially directed the students to work individually on comprehension questions based on a text. Then, they were grouped and told to exchange their written answers, taking turns to comment on them. For example, one student would read what she had written; her peers would note if her answer matched theirs; and if not, they would decide together which answer was correct. Although the teachers referred to this sequence as an example of collaborative learning through discussion, it does not reflect definitions that emanate from constructivist perspectives. Constructivist definitions suggest that such activities involve two or more students actively interacting with each other to construct knowledge; search for understanding, meaning, or solutions; or create a product of their learning (Harding-Smith, 1993; Vermette, Harper, \& Dimillo, 2004).

Thirdly, activities observed in the teachers' writing lessons were skill-based practices that commonly occur in the traditional approach, such as copying and dictation (Browne, 2009). The purpose reported by the teachers was to practice cursive handwriting skills or to focus on accuracy of punctuation-use conventions such as capital letters and full stops. For example, eight writing activities involved copying sentences or a poem written on the board or from a textbook, and these occurred in eight different classrooms. Twelve writing activities observed focused on dictation exercises, which required students to write several sentences dictated by the teacher. The sentences were already familiar to the students through whole-class activities. These activities typically followed a pattern where the students as a group read a short text from their textbooks, guided by their teacher. Next, they practiced making simple oral sentences based on that text. Then, some students were nominated to write the sentences on the board with the teacher's assistance. Finally, the teacher dictated these practiced sentences while their students wrote them out. Three writing activities required the students to answer questions about a short text from a textbook they had read, and this was designed to test their comprehension, handwriting and the use of capital letters and full stops. These questions were typically literal with one correct answer available in the text. Five writing activities involved students completing sentences or cloze passages by selecting the correct word from those provided on the worksheet to complete sentences related to a topic such as animals. The teachers viewed this activity as providing the structure their students needed, as illustrated by 
this teacher quotation from a post-observation discussion: "This is just grade two; we have to show the students how to make sentences step by step first". The remaining two lessons showed that students were given the opportunity to write a recount independently. However, the focus as reported by the teachers remained on accuracy, correct punctuation and neat, correct handwriting.

In addition to their practices and lesson content reflecting a traditional approach to teaching writing, teachers also spoke about their understanding of the KTSP, which helped to elucidate the practices observed. During the discussions and interviews, seven teachers spoke about the key pedagogical concepts of the KTSP but reported that they did not understand them or how to implement them in their teaching, as exemplified in the following quote:

I am aware that under the KTSP, teachers should be facilitators. But I am not sure what facilitator really means. In my class, I facilitate learning by explaining the lesson first and then asking my students to practice. That's my understanding.

Three teachers used terminology consistent with the key concepts of the KTSP; yet they interpreted and implemented them in ways that were more consistent with a traditional view of learning, as was exemplified in the following quotation from one of the teachers:

Being a facilitator means it is not only the teacher who is active all the time but students must be also. Nevertheless, as teachers, we must explain the task first, and then let the students do it by themselves.

Evidence from observations of this teacher suggests that the very act of letting "the students do it by themselves" was interpreted as students being active. However, in essence, the students were simply responding to instructions.

Finally, the teachers demonstrated a traditional approach to teaching writing in their assessment practices. This was evident in their lesson plans, the classroom observations, informal discussions and students' samples of writing. In all teachers' lesson plans, assessment focused on the secretarial aspects or surface features of the writing products the students generated. The observations, informal discussions and the students' assessed samples of writing provided further evidence that the assessment focused on low-level writing skills, such as neat cursive handwriting and sentence-level punctuation, regardless of the type of writing being completed. Moreover, all the teachers reported that assessment was based on the products, not process, of writing, used scoring or grading of the low-level skills and was completed by them without student involvement. While two teachers reported that they used writing portfolios, they did so to organize students' writing products rather than to assess their writing development over time.

Finding one suggests that the teachers' classroom practices were inconsistent with the constructivist learning perspective informing the KTSP and that they retained their traditional practices when implementing the new curriculum. Teachers' retention of existing traditional methods in the face of directives to change their practices to reflect a learner-centered approach has also been found in other contexts (Blignaut, 2008; DeSegovia \& Hardison, 2009). 
By the teachers' admission, the finding in this present study was in large part due to their lack of knowledge of the pedagogical concepts underpinning the KTSP and how to enact these in their classrooms. This finding is consistent with previous research conducted by the Indonesian Centre of Curriculum (Pusat Kurikulum, 2007), which found that teachers did not understand the substance of the KTSP, or know how to implement it in ways consistent with its core concepts. This finding supports the view that effective change will only occur if teachers, as key curriculum implementers, have a clear understanding of the change itself and have the opportunity to develop critical new knowledge, skills and attitudes (Fullan, 2007). In order to promote deep change in practice, teachers require new ways of thinking and behaving, and the acquisition of new knowledge and skills (Fullan, 2007; Fullan \& Hargreaves, 1992; Guskey, 2000; Little, 2001).

In this study, the teachers' insufficient skills and knowledge to meet the demands of the new curriculum may have been influenced by the nature of the PD they had so far received. Although all of the teachers claimed to have attended PD in preparation for the implementation of the KTSP, nine of them only had access to a one-day session, which did not seem to provide the depth of understanding required by the KTSP. In addition, only two teachers attended PD specifically focused on literacy subjects or teaching methods encouraged by the KTSP. Previous studies have shown that PD is more effective when it is offered for a longer period, involves more time and is comprehensive (Garet et al., 2001; Peneul et al., 2007). Similarly, Guskey (2000) argues that once-off programs do not support the implementation of new curricula since curriculum change is a complex process (Brady \& Kennedy, 1999; Fullan, 2007); therefore, teachers need time to understand and implement a new curriculum in ways consistent with its requirements (Little, 2001). This is particularly the case for Indonesian teachers for whom constructivism represents a fundamental change in all aspects of their teaching and learning processes, including a role change from knowledge transmitter to learning facilitator, which implies that a totally different set of pedagogical skills is required (Weimer, 2002). Further, the teachers in this study may have remained with familiar practices because of a lack of support extended to help them understand and implement the new curriculum, as has been found in other studies (Broadhead, 2001).

Finding 2: Teachers in this study restricted their teaching to achieving the basic competencies for Y2 when implementing the writing component of the KTSP.

All 10 teachers in this study appeared to limit their teaching focus to achieving the basic competencies for Y2 when implementing the writing component of the KTSP. This focus was evident during the classroom observations where all the teachers organized their lessons based on the competencies outlined by the Curriculum Policies. The activities they assigned their students addressed the competencies and included copying poems from textbooks, copying teachers' writing from the blackboard, writing sentences dictated or modeled orally by the teachers, completing stories by filling in missing words and writing one or two simple sentences about animals. One teacher stated: 
I know that the KTSP should be student-centered. But I don't know what it means and how to apply it. I just focus on the competency and give [the students] activities that will achieve these competencies.

Further, most of the writing products $(\mathrm{N}=90)$ collected for analysis after the classroom observations reflected this orientation, being copied text or poems $(n=24)$, or sentences that had been dictated by the teachers or written after oral practice $(n=36)$. In addition, there were samples that were answers to questions or completed cloze passages $(n=24)$. A teacher summed up the focus on the competencies in the following comment:

When planning the syllabus and lesson plans, we always start by looking at the competency, both the Competency Standards and Basic Competencies. We plan our lessons based on these standards. I choose activities that help to meet the competencies.

Similarly, the competencies strongly shaped the teachers' assessments, in that these focused on low-level writing skills. This was particularly evident in the classroom observations, informal discussions, interviews and the manner in which the teachers evaluated their students' samples of writing. That is, the 90 writing samples collected were all mainly assessed on the basis of the neatness and accuracy of the handwriting, and the use of simple punctuation, as confirmed by the teachers in the informal discussions and interviews. Further, in all of the 30 analyzed observations, the teachers were observed to regularly remind their students to use neat cursive handwriting and correct punctuation, giving directives and reminders such as, "Don't forget to use cursive handwriting", "Make sure you write neatly with cursive handwriting that I have taught you", or "Those who don't make mistakes in using capital letters and full stops will get a high score". Consistent with this emphasis, the teachers selected what they considered to be exemplary samples of student writing based on neat handwriting and minimal mistakes in the use of capital letters and full stops.

The emphasis on the basic competencies in the teachers' assessment practices was confirmed in the interviews following the observations when some teachers stated that the learning competencies for Y2 writing lessons are to be able to write neatly and correctly, and this was why they noted these in their lesson plans and syllabi. This suggests that their assessment was based on these competencies regardless of whether the activity was copying, rewriting stories or writing simple sentences. As one teacher expressed it, "I assessed my students on the competencies to be achieved ... and that was using neat cursive handwriting and correct use of capital letters and full stops". This suggests that the teachers interpreted the competencies in a narrow way that emphasized the learning of low-level skills rather than focusing on the writing process itself.

Further, even though an analysis of the writing samples collected in this study suggested that many students were already capable of using simple punctuation and neat handwriting, the teachers' focus remained on these aspects. Consequently, in the observed lessons, the students were rarely offered opportunities to produce their own written texts, despite evidence that some were capable of doing so. For example, in two observed lessons, the students were given the opportunity to write a recount and, although the writing of different genre types had not yet 


\section{Al Macrothink}

been taught in Y2, their writing samples showed that they were capable of communicating their own ideas and in following most of the conventions of a recount. This is evident in the writing sample below (Figure 1) where the student used an opening and a brief conclusion, reported events in sequence and used appropriate vocabulary to present content relevant to the topic assigned by the teacher.

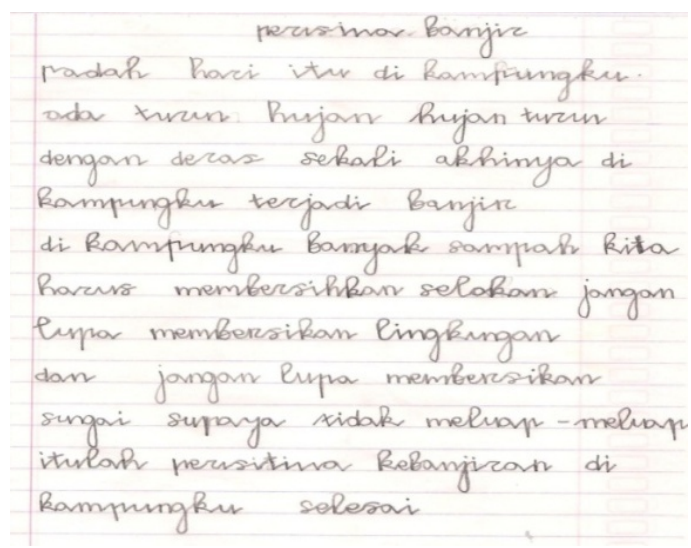

Figure 1. Sample of a recount

This text translates as follows:

\section{flood moment}

one day in my village it rained heavily eventually it was flooded in my village there was a lot of rubbish we had to clean it from the ditch we did not forget to clean the river so that it would not overflow that was the flood moment in my village the end

Although this activity gave the students the opportunity to write their own texts and would suggest a broader interpretation of the competencies, the teacher's focus in the lesson itself and the assessment of its products remained on accuracy, correct punctuation and neat, correct handwriting. This was evident in the observations and interviews when one of the teachers expressed her approach in the following way:

The content was relevant to the given theme as it talked about the flood. The spelling was correct and the writing was cursive and legible. However, the student still needed to improve the use of capital letters and punctuation.

The teachers' comments during the discussions and interviews demonstrated that their pedagogical choices were made to specifically meet the competencies, for instance:

As you have seen in my lesson, I started by reviewing the previous lesson and then I explained. After that, the students had an opportunity to practice individually or with friends in a group. I think this way is better to achieve the competencies.

In addition, several explained the need to be pragmatic in order to meet the competencies, saying for instance, "It is practical to teach this way ... it is an effective way to achieve the 
goals". The influence of the competencies on the teachers' practices suggests they were using backward design (Wiggins \& McTighe, 2005).

The findings from the study suggest that the negative influence of the basic competencies on the teachers' implementation of the pedagogical underpinnings of the new curriculum was due to three factors. First, some of the expected Basic Competencies prescribed in the Curriculum Policies for writing in Y2 appear to be very skill-based, thereby encouraging the teachers to take a pragmatic view and teach these through teacher-centered methods. The influence of the competencies also appears to have led the teachers to use traditional assessment practices to assess a narrow range of low-level skills, such as handwriting and simple punctuation.

Second, findings in the study suggest that the teachers interpreted the competencies in a narrow way, consistently associating the expected writing competencies with low-level writing skills such as neat handwriting and copying. This interpretation occurred despite some of the competencies outlined in the curriculum guidelines being relatively broad. For example, Basic Competency 1, completing a simple story by using correct words, and Basic Competency 3 , concerned with students' ability to describe plants or animals in simple sentences using written language, appear to be relatively broad, giving flexibility to teachers to provide learning activities that promote a higher order of thinking and thereby encourage their students to learn higher-level skills such as composing their own text. In contrast, Basic Competencies 2 and 4 seem to be relatively narrow and skill-based, promoting the learning of low-level writing skills such as copying. However, regardless of these different types and levels of writing activities suggested by the four competencies, the teachers very often associated the competencies with activities that focused on the low-level writing skills.

Third, the teachers' use of backward design seemed to encourage them to employ a traditional approach in which they transmitted knowledge to their students. Although this design has been found to be effective approach in other studies (Fox \& Doherty, 2011; Graff, 2011), evidence from the current study suggests that in this context it discouraged the teachers from selecting teaching and learning activities that allowed students to construct their own knowledge. As has been shown, the teachers interpreted the competencies in a narrow manner and so selected pedagogical approaches that emphasized the development of low-level skills through teacher-directed activities. The evidence suggests that the compatibility of this approach with their existing practices and knowledge encouraged its retention.

These findings are consistent with those of other studies of competency-based education and the influence of backward design, which suggest behavioral approaches are predominantly selected by teachers if the learning outcomes to be achieved are very prescriptive, skill-based and narrow (Kouwenhoven, 2003; Wiggins \& McTighe, 2005). Although Wiggins and McTighe (2005) maintain that backward design can facilitate constructivist-oriented pedagogy, the emphasis on low-level skills in most of the KTSP competencies and the teachers' narrow interpretation of the broader aspects of the other competencies, encouraged them to continue to use familiar didactic approaches to instruction.

The evidence suggests it may be extremely challenging for teachers to incorporate active learning methods into their teaching if the expected competencies themselves are very narrow 
and skill-based, as was the case in this study. Thus, it would appear that the teachers were indirectly encouraged to continue to take a traditional approach to teaching by the narrow and skill-based competencies required, coupled with their narrow interpretation of them and the use of backward design.

\section{Conclusion}

The teachers' lack of knowledge and understanding about the pedagogical practices promoted by the new curriculum and the nature of the competencies, together with their narrow interpretation of these, seems to have influenced, if not overtly encouraged, the retention of traditional approaches to pedagogy. These findings have serious implications for more effective curriculum change. Firstly, it needs to be recognized that the implementation of a new curriculum at the classroom level is extremely challenging for teachers if they do not possess adequate knowledge of the changes expected. Therefore, in-depth and ongoing PD and support for teachers is a crucial element of effective curriculum change and should also become an expected element of educational policy design. Secondly, the serious mismatch between the prescribed competencies and the constructivist approach to teaching and learning in the KTSP discouraged the teachers in this study from implementing the desired new approaches to teaching and assessment. Therefore, there is a compelling need to ensure consistency between the underlying philosophical and pedagogical practices promoted by a curriculum and the learning outcomes expected as a result of its implementation. The findings from this study indicate that failure to address these aspects of the change process will encourage teachers either to retain their current practices or implement superficial change. This would seem to be particularly the case where the curriculum change requires a considerable shift in pedagogical practices, such as was the case for the teachers in this study. Further research is needed to investigate the relationship between prescribed competencies and pedagogy, particularly in relation to the competencies being standardized in a mandated curriculum framework.

\section{Acknowledgement}

The first author would like to thank the Directorate of Higher Education, Republic of Indonesia, for providing a scholarship for this study through the BERMUTU Project and to employers at University of Muhammadiyah Makassar, Indonesia, for their continuous support throughout this study. Thanks are also due to Rachel Wheeler of Edith Cowan University, Western Australia, for her valuable help in preparing this paper.

\section{References}

Alesandrini, K., \& Larson, L. (2002). Teachers bridge to constructivism. The Clearing House, 75(3), 118-122. http://dx.doi.org/10.1080/00098650209599249 
Blignaut, S. (2008). Teachers' sense making and enactment of curriculum policy. Journal of Education, 43, 102-126.

Bowden, J. A. (1997). Competency-based education: Neither a panacea nor a pariah. Paper presented at the Conference on Technological Education and National Development, Abu Dhabi, United Arab Emirates. ERIC database (ED 445 263).

Brady, L., \& Kennedy, K. (1999). Curriculum construction. Erskineville, NSW: Prentice Hall.

Broadhead, P. (2001). Curriculum change in Norway: Thematic approaches, active learning and pupil cooperation - from curriculum design to classroom implementation. Scandinavian Journal of Educational Research, 45(1), 19-36. http://dx.doi.org/10.1080/00313830020023375

Browne, A. (1993). Helping children to write. London: Paul Chapman Publishing Company.

Browne, A. (2009). Developing language and literacy 3-8 (3rd ed.). London: Sage.

BSNP. (2006). Panduan penyusunan kurikulum tingkat satuan pendidikan jenjang pendidikan dasar dan menegah [A guideline to develop school-based curriculum for primary and secondary schools] Jakarta: Badan Standar Nasional Pendidikan [Board of National Standard of Education], DepartemenPendidikanNasional.

Cox, C. (2005). Teaching language arts: A student- and response-centered classroom (5th ed.). Needham Height, MA: Allyn and Bacon.

Creswell, J. W. (2012). Educational research: Planning, conducting, and evaluating quantitative and qualitative research (2nd ed.). Thousand Oaks, CA: Sage Publications.

Curtner-Smith, M. D. (1999). The more things change the more they stay the same: Factors influencing teachers' interpretations and delivery of National Curriculum Physical Education. Sport, Education and Society, 4(1), 75-97. http://dx.doi.org/10.1080/1357332990040106

DeSegovia, L. P., \& Hardison, D. M. (2009). Implementing education reform: EFL teachers' perspectives. ELT Journal, 63(2), 154-162.

Fosnot, T. (2005). Constructivism: Theory, perspective, and practice (2nd ed.). New York: Teacher College Press.

Fox, B., \& Doherty, J. (2011). Design to learn, learn to design. Communication in Information Literacy, 5(2), 144-155.

Fullan, M. G. (2007). The new meaning of educational change (4th ed.). New York, NY: Teachers College Press, Columbia University.

Fullan, M. G., \& Hargreaves, A. (1992). Teacher development and educational change. In M. Fullan \& A. Hargreaves (Eds.), Teacher development and educational change (pp. 1-9). London: Falmer Press. 
Fullan, M. G., \& Pomfret, A. (1997). Research on curriculum and instruction implementation. Review of Educational Research, 47, 335-397. http://dx.doi.org/10.3102/00346543047002335

Fullan, M. G., \& Stiegelbauer, S. (1991). The new meaning of educational change. New York, NY: Teachers College Press.

Garet, M. S., Porter, A. C., Desimone, L., Birman, B. F., \& Yoon, K. S. (2001). What makes professional development effective? Results from a national sample of teachers. American Educational Research Journal, 38(4), 915-945. http://dx.doi.org/10.3102/00028312038004915

Graff, N. (2011). An effective and agonizing way to learn: Backwards design and new teachers' preparation for planning curriculum. Teacher Education Quarterly, 38(3), 151168.

Guskey, T.R. (2000). Evaluating professional development. Thousand Oaks, California: Corwin Press Inc.

Harding-Smith, T. (1993). Learning together: An introduction to collaborative learning. New York, NY: Harper Collins College Publishers.

Kaufman, D. (2004). Constructivist issues in language learning and teaching. Annual Review of Applied Linguistics, 24, 303-319. http://dx.doi.org/10.1017/s0267190504000121

Kouwenhoven, G. W. (2003). Designing for competence: Towards a competence-based curriculum for the faculty of education of the Eduardo Mondlane. (Doctoral Dissertation), Twente University, Enschede.

Little, J. W. (2001). Professional development in pursuit of school reform. In A. Lieberman \& L. Miller (Eds.), Teachers caught in the action: Professional development that matters. New York, NY: Teachers College Press.

Marsh, C. J. (2004). Key concepts for understanding curriculum (3rd ed.). Abingdon, Oxon: Routledge Falmer.

MBE Project. (2003). Summary of findings. Retrieved from http://mbeproject.net

Muslich, M. (2007). KTSP pembelajaran berbasis kompetensi dan kontekstual [School-Based Curriculum (SBC) a contextual and competency-based learning]. Jakarta: Bumi Aksara.

Obara, S., \& Sloan, M. (2009). Classroom experiences with new curriculum materials during the implementation of performance standards in mathematics: A case study of teachers coping with change. International Journal of Science and Mathematics Education, 8, 349-372. http://dx.doi.org/10.1007/s10763-009-9176-9

Penuel, W. R., Fishman, B. J., Yamaguchi, R., \& Gallagher, L. P. (2007). What makes professional development effective? Strategies that foster curriculum implementation. American Educational Research Journal, 44(4), 921-958. http://dx.doi.org/10.3102/0002831207308221 
Perrott, C. (1988). Classroom talk and pupil learning: Guidelines for educators. Marrickville, NSW: Harcourt Brace Jovanovich Group.

Peraturan Menteri Pendidikan Nasional No. 24, Pelaksanaan SI dan SKL [Ministerial of National Education Decree No 24, The implementation of Content Standards and Graduate Competency Standards]. (2006).

PP No. 19, Standar Nasional Pendidikan [Government Regulation No. 19, The National Standard of Education]. (2005).

Priestley, M. (2011). Schools, teachers, and curriculum change: A balancing act? Journal of Educational Change, 12(1), 1-23. http://dx.doi.org/10.1007/s10833-010-9140-z

Pusat Kurikulum. (2007). Laporan hasil pemantauan pelaksanaan Standar Isi dan Standar Kompetensi kelulusan [A report on monitoring findings on the implementation of Content Standard and Graduate Competency Standard]. Jakarta: Badan Penelitian dan Pengembangan, Depdiknas [Research and Development Board, Department of National Education].

Pusat Kurikulum. (2010). Bunga rampai kurikulum pendidikan: Buku kedua [A collection of essays on educational curriculum. The second book]. Jakarta: Badan Penelitian dan Pengembangan Depdiknas [Research and Development Board, Department of National Education].

Putman, S. M., Smith, L. L., \& Cassady, J. C. (2009). Promoting change through professional development: The place of teacher intentionality in reading instruction. Literacy Research and Instruction, 48(3), 207-220. http://dx.doi.org/10.1080/19388070802251988

Robson, C. (2011). Real world research: A resource for users of social research methods in applied settings (3rd ed.). Chichester, West Sussex; Hoboken, New Jersey: Wiley-Blackwell.

Sanjaya, W. (2008). Kurikulum dan pembelajaran: Teori dan praktik pengembangan Kurikulum Tingkat Satuan Pendidikan (KTSP) [Curriculum and learning: Theory and practice for School-Based Curriculum (SBC) development]. Jakarta: KencanaPrenada Media Group.

Sari, E. R. (2012). Teacher professional development in an online learning community: A case study in Indonesia. (Doctoral dissertation), Edith Cowan University, Perth, Western Australia.

Stronge, J. H. (2010). Effective teachers = Student achievement: What the research says. Larchmont, NY: Eye on Education.

Tompkins, G.E. (2008). Teaching writing: Balancing process and product. Upper Saddle River, New Jersey: Pearson Education.

Vermette, P., Harper, L., \& DiMillo, S. (2004). Cooperative and collaborative learning with 
4-8 year olds: How does research support teachers' practice? Journal of Instructional Psychology, 31(2), 130-134.

Vygotsky, L.S. (1978). Mind in society. Cambridge, MA: MIT Press.

Weimer, M. (2002). Learner-centered teaching. San Fransisco, California: Jossey-Bass.

Wiggins, G., \& McTighe, J. (2005). Understanding by design (2nd ed.). Upper Saddle River, NJ: Prentice Hall.

Windschitl, M. (2002). Framing constructivism in practice as the negotiation of dilemmas: An analysis of the conceptual, pedagogical, cultural, and political challenges facing teachers. Review of Educational Research, 72(2), 131-175. http://dx.doi.org/10.3102/00346543072002131

\section{Copyright Disclaimer}

Copyright for this article is retained by the author(s), with first publication rights granted to the journal.

This is an open-access article distributed under the terms and conditions of the Creative Commons Attribution license (http://creativecommons.org/licenses/by/3.0/). 